\title{
Genesis of Rare-element Pegmatites at Kalu'an, the Chinese Altay: Insights from Columbite U-Pb dating and Melt Inclusion Study
}

\author{
YONGGANG FENG ${ }^{1}$, TING LIANG ${ }^{2}$, ROBERT LINNEN ${ }^{3}$, \\ XIJUAN TAN ${ }^{4}$ \\ ${ }^{1}$ Laboratory of Mineralization and Dynamics, Chang'an \\ University, Xi'an, China, 7100542, ygfeng@chd.edu.cn \\ ${ }^{2}$ Laboratory of Mineralization and Dynamics, Chang'an \\ University, Xi'an, China, 7100542, liangt@chd.edu.cn \\ ${ }^{3}$ Department of Earth Sciences, Western University, London, \\ Ontario, Canada, N6A 3K7, rlinnen@uwo.ca \\ ${ }^{4}$ Laboratory of Mineralization and Dynamics, Chang'an \\ University, Xi'an, China, 7100542, \\ tanxijuan@hotmail.com
}

The Kalu'an pegmatite field, one of the most important rare-metal metallogenic regions in China, hosts a large number of rare-element pegmatite dikes belonging to spodumene and lepidolite subtypes. Columbite $\mathrm{U}-\mathrm{Pb}$ dating reveals three emplacement ages, namely, 224.3 $\pm 2.9 \mathrm{Ma}$ $(2 \sigma), 209.5 \pm 1.4 \mathrm{Ma}(2 \sigma)$, and $198.3 \pm 2.0 \mathrm{Ma}(2 \sigma)$, indicating that there were three emplacement events of the Lirich pegmatite-forming melts in a timeframe of $\sim 30 \mathrm{Ma}$. In combination with previous studies, we conclude that the $\mathrm{Li}$ pegmatites were formed before the $\mathrm{Be}-\mathrm{Ta}-\mathrm{Nb}$ pegmatites $(\sim 194-192 \mathrm{Ma})$ in the same region, which precludes the genesis of rare-metal pegmatites via fractional crystallization of a granitic magma in the Kalu'an region.

Coexisting fluid and melt inclusions are present in early crystallized beryl from the $\mathrm{Li}$ pegmatites. Raman spectroscopy indicates a variety of crystalline phases (mainly including quartz, feldspar, and ploylithiolite) in the melt inclusions. By contrast, calcite, barite, and possibly phenakite occur as daughter minerals in the coexisting fluid inclusions. In addition, $\mathrm{CO}_{2}$ and $\mathrm{N}_{2}$ are constantly present in the vapor phases of both melt and fluid inclusions. Rehomogenization using a cold-seal pressure vessel at $\sim 1.1 \mathrm{kbar}$ shows that the melt inclusions are homogenized at $625-650{ }^{\circ} \mathrm{C}$. The emplacement pressure is then estimated to be $\sim 3.8 \mathrm{kbar}$ in light of the water saturation curve for granitic melts. The primary fluid inclusions with a salinity of $10.6-18.2 \mathrm{wt} . \%$ $\mathrm{NaCl}_{\text {eq. }}$ in spodumene are homogenized at $278-305{ }^{\circ} \mathrm{C}(295$ ${ }^{\circ} \mathrm{C}$ on average). Assuming that the pressure remained constant during pegmatite crystallization, the temperature for the Li mineralization is likely $600{ }^{\circ} \mathrm{C}$. 